\title{
Azərbaycanda informasiya təhlükəsizliyi milli maraqlar kontekstində
}

\author{
Elşad Həsənli \\ İnformasiya Texnologiyaları İnstitutu, Bakı, Azərbaycan \\ xeber36aztv.az
}

\begin{abstract}
Xülasə- Beynəlxalq aləmdəki müasir vəziyyət, siyasi qarşıdurmalara meylliliyin müşahidə olunduğu indiki vaxtda hər bir dövlətin və cəmiyyətin təhlükəsizliyinin qorunması, insanların həm siyasi, həm də digər maraqlarının təmin olunması mühüm vəzifələr sırasındadır. Elm və texnikanın, informasiya texnologiyalarının inkişaf etdiyi vo geniş tətbiq olunduğu müasir şəraitdə informasiya təhlükəsizliyi xüsusilə aktualdır. Milli maraqların xarakteri, onların dövlət siyasətinin bütün istiqamətlərində, o cümlədən informasiya təhlükəsizliyi sahəsində prioritet yer tutması todqiqat obyektidir. Tədqiqatda Azərbaycan Respublikasında informasiya təhlükəsizliyinin təmin olunması ilə bağlı görülmüş işlər təhlil edilmiş, bu sahədə xarici təhdidlərin qarşısının alınması üçün zəruri tədbirlərdən bəhs edilmişdir.
\end{abstract}

Açar sözlor- milli tohlükosizlik, informasiya tohlükosizliyi, milli maraqlar, hibrid müharibəlori, terrorizm, multikulturalizm, media

\section{GİRIŞ}

Dövlətin və millətin mövcudluğu üçün zəruri olan təhlükəsizlik və milli maraqlar bir-birini tamamlayan əsas faktorlardır. Belə ki, təhlükəsizlik mühiti olmadan milli maraqlar, milli maraqlar təmin edilmədikdə isə təhlükəsizlik şəraiti yaradıla bilməz. Geniş mənada təhlükəsizlik ölkənin, millətin, xalqın və nəhayət, hər bir vətəndaşın fəaliyyətinin, yaşam tərzinin təməl daşıdır, sabitliyin qarantıdır. Milli, iqtisadi, hərbi siyasətin əsas məqsədi sabitliyin təmin olunmas1, təhlükəsizlik mühitinin yaradılmasıdır. Çoxmillətli, çoxkonfessiyalı cəmiyyətin mövcud olduğu Azərbaycan Respublikasında əsrlərdən gələn birgəyaşayış, milli və dini dözümlülük mühiti buradakı insanların hüquqlarının təmin olunmasında əsas rol oynayır. İnsanlarda milli şüur və siyasi şüurun formalaşması, qədim ənənələrin bu günə daşınması onun inkişafının mühüm amillərindəndir. $\mathrm{Bu}$ yöndə ideoloji təbliğatın aparılması və zəruri informasiya mühitinin yaradılması da mühüm əhəmiyyət kəsb edir.

Müasir şəraitdə dünya düzənində informasiya təhlükəsizliyi və digər təhlükəsizlik məsələlərini yönləndirən ideologiyada deqradasiya və konfrantasiya müşahidə olunmaqdadır. Bir sıra aparıcı ölkələrin yürütdüyü siyasət bəşəriyyətin gələcəyi üçün müəyyən şübhələr yaradır, sanki beynəlxalq ictimaiyyət nasizm girdabına sürüklənir. Beynəlxalq iqtisadi böhran şəraitində özünü biruzə verən bu hal dövlətlər, millətlər və xalqlar arasında inamsızlığa səbəb olur. Dünyanın bir qütbündə tolerantlıq, multikulturalizm çağırışlarına üstünlük verildiyi, birgəyaşayışa cəhd edildiyi halda, digər qütbündə islamafobiya bəhanəsi ilə müsəlmanlara qarş1 məqsədyönlü siyasət formalaşdırılır. İndi bəzi ölkələrdə irqi ayrı-seçkilik və düşmənçiliyə meyl edən siyasətçilərin hakimiyyyət başına gətirilməsi deyilənlərin əyani sübutudur.

\section{INFFRMASIYYA TӘHLÜKӘSİLIYYİ MILLI MARAQLARI TOMIN EDӘN AMIL KIMI}

$\mathrm{Bu}$ gün ərazicə kiçik, əhalisinin sayı az olan, müsəlman etiqadlı Azərbaycan ədalətlilik, tolerantlıq, dözümlülük və multikultural dəyərlərə hörmətlə yanaşan dövlət kimi aparıcı ölkələrə nümunə göstərir. $\mathrm{Bu}$ ideoloğiyanın kökündə isə qədim dövlətçilik ənənələri dayanır. Azərbaycanda informasiya təhlükəsizliyi ilə bağlı məsələlər ölkə qanunlarında öz əksini tapıb. $\mathrm{Bu}$ qanunlar əsasən aşağıdakılardır:

- Kütləvi informasiya vasitələri haqqında Azərbaycan Respublikasının Qanunu;

- Məlumat azadlığı haqqında Azərbaycan Respublikasının Qanunu;

- İnformasiya əldə etmək haqqında Azərbaycan Respublikasının Qanunu;

- İnformasiya, informasiyalaşdırma və informasiyanın mühafizəsi haqqında Azərbaycan Respublikasının Qanunu;

- Telekommunikasiya haqqında Azərbaycan Respublikasının Qanunu;

- Televizya və radio yayımı haqqında Azərbaycan Respublikasının Qanunu;

- Dövlət sirri haqqında Azərbaycan Respublikasının Qanunu və s.

Qeyd edək ki, informasiya təhlükəsizliyinin təmin olunması ilə bağlı tələblər bir sira digər qanunlarda, o cümlədən "Milli təhlükəsizlik haqqında" Azərbaycan Respublikasının Qanununda, eləcə də Azərbaycan Respublikasının Milli Təhlükəsizlik Konsepsiyasında göstərilib. Bütün bu sənədlərdə qeyd olunur ki, informasiya təhlükəsizliyinin təmin olunması məsələləri ümumilikdə dövlət, ictimai və fərdi informasiya ehtiyatlarının qorunmasına, eləcə də informasiya sahəsində milli maraqların qorunmas1 və mühafizəsinə əsaslanır. Milli maraqların mühafizəsi və bu sahədə səmərəli fəaliyyətin təmin olunması üçün təhlükəsizlik konsepsiyasında dövlətin kəşfiyyat 


\section{"Informasiya tohlükosizliyinin aktual problemlori” \\ III respublika elmi-praktiki seminarı, 08 dekabr 2017-ci il}

qabiliyyətinin uzlaşdırılması, tədbirlər kompleksinin həyata keçirilməsi, həmçinin məxfi informasiyanın mühafizəsinin koordinasiyalı şəkildə təmin edilməsi nəzərdə tutulub. Azərbaycan Respublikasında hər bir şəxsin informasiya əldə etmək, yaymaq hüququ var, hər bir vətəndaşın söz, mətbuat və informasiya azadlığı qanunvericilkdə təsbit olunub. Lakin bu hüquqlar qanunlar konpleksinin tələblərini pozmamalıdır. Məlumatların qanuni yolla əldə olunmas1, hazırlanmas1, yayılması, ölkə və dünya rabitə və informasiya məkanına daxil edilməsi qanun çərçivəsində mümkündür. $\mathrm{Bu}$ tələblərin pozulması hüquqi məsuliyyət yaradır. "Milli Təhlükəsizlik Haqqında" Azərbaycan Respublikasının Qanununun 7-ci maddəsində göstərilir ki, milli maraqların həyata keçirilməsinə mane olan, onlara təhlükə yaradan şərait, proses və amillər Azərbaycan Respublikasının milli təhlükəsizliyinə təhdidlər yaradır. Siyasi elmlər doktoru, professor Hikmət Babaoğlu yazır ki, "hər bir xalqın milli mətbuatı daimi milli və dövlət maraqlarına xidmət etməlidir. Olbəttə ki, mətbuatın başlıca funksiyası cəmiyyəti obyektiv, tərəfsiz və qərəzsiz informasiya ilə təmin etməkdir. Bu pirinsip, yalnız o hallarda pozula bilər ki, ortada ümumi, ictimai, milli və dövlətçilik maraqları olsun" [3] .

Ölkənin milli təhlükəsizlik sisteminin qurulmasında nəzərə alınmalı amillərdən biri də miqrasiya problemidir. Buraya həm daxili, həm də xarici miqrasiya aiddir. Azərbaycan daxili miqrasiya ilə bir neçə dəfə üzləşib. Bu, əsasən keçmiş SSRİ rəhbərliyinin yürütdüyü birtərəfli milli siyasət, sonrakı dövrdə isə Ermənistanın ölkəmizə təcavüzü ilə əlaqədardır. Həm çar Rusiyası, həm də Sovet Rusiyasının qədim Azərbaycan ərazilərini erməniləşdirmək və özünə əlverişli coğrafi, siyasi və strateji-hərbi mövqe yaratmaq, qardaş Türkiyə və qonşu İranla Azərbaycanın əlaqələrini məhdudlaşdırmaq məqsədi daşıyan bu tədbirlər nəticəsində azərbaycanlılara məxsus ərazilər tutuldu, köçürülmə nəticəsində daxili miqrasiya baş verdi. XX əsrin əvvəllərində (1905-1918), ortalarında (19481949) və 80-ci illərdə baş verən miqrasiyanın kuliminasiyası 1988-ci ildə oldu. 18-19-cu əsrlordə İrəvandak1 ümumi əhalinin $85 \%$-ni azərbaycanlılar təşkil edirdisə, hazırda burada soydaşlarımız yoxdur. 1990-cı illərdə Azərbaycanın öz sərhədlərinə daxil olan 12 rayondan da insanlar hərbi təcavüzə məruz qaldı və yeni qaçqın axını baş verdi. Hazırda ölkəmizdə 1 milyondan çox azərbaycanlı məcburi köçkün həyatı yaşayır. Lakin ölkə rəhbərliyinin apardığı düzgün siyasət və görülmüş zəruri tədbirlər sayəsində daxili təhlükəsizlik təmin olunub və miqrasiya ilə bağlı problemlər həll olunub. Heç də təsadüfi deyil ki, bu gün miqrasiya problemi yaşayan və Yaxın Şərqdən gələn qaçqınlar qəbul etməkdə çətinlik çəkən Avropa ölkələrinin bəziləri Azərbaycan nümunəsini örnək kimi görür, bəziləri isə qaçqınların gəlişinə etiraz edirlər. Buradan belə bir qənaətə gəlmək olar ki, bir sira ölkələrdə humanitar böhran və ideoloji təbliğat yönündə iş düzgün qurulmayıb və şovinist əhval-ruhiyyəli cəmiyyət bunu istəmir. Başqa sözlə desək, həmin ölkələrdə ideoloji və informasiya təhlükəsizliyi təmin olunmayıb, onlarda konfliktə meyllilik güclüdür. Bəzi dövlətlərdə faşizm, nasizm ideologiyası getdikcə güclənməkdədir. Bir zamanlar demokratiyanın beşiyi adlandırılan ölkələrdə belə, antihumanist ideologiya dərinləşib, islamafobiya meylləri özünü daha qabarıq göstərir. Rusiyalı alim, politoloq S. Nikonov yazır ki, “ovvəllər siyasətçilər informasiya məkanını formalaşdırırdı, indi isə informasiya dünya siyasətini formalaşdırır" [7].

\section{TӘHLÜKəSIZLIYЭ TəHDID: HIBRID MÜHARIBӘLӘR}

Dünyanın aparıcı gücləri-ölkələri və təşkilatları istər beynəlxalq aləmdə, istərsə də öz dövlətlərində hər hansı ciddi problem və məsələ ilə bağlı ictimai rəy formalaşdırmaq, tərəfdarlar tapmaq üçün informasiyadan və ümumilikdə KİVdən istifadə edirlər. Beləliklə, öz maraqlarının təbliği və qarşı tərəfin gözdən salınması kampaniyası başlanır. Bununla da KIV bəzən haql1, ədalətli, bəzən də qeyri-obyektiv mövqedən çıxış etməli olur. Dünyamızın qarışıq olduğu indiki vaxtda isə obyektiv mövqeyi heç də həmişə qoruyub saxlamaq mümkün deyil. Zaman sübut edir ki, indiki informasiya mübarizəsində üstün olan dövlət uğur qazanır, öz tələblərini diqtə edir, bəzən də münaqişə yaradır. Təbliğat vasitəsinə çevrilən KİV-lər isə onun tribunası rolunu oynayır. Bunu bir çox dövlət rəhbərləri də etiraf edirlər. Məsələn, Belarus Respublikasının Prezidenti A. Lukaşenko Ümumdünya Rus Mətbuatı Konqresində çıxışı zamanı deyib ki, “ KIV tez-tez hibrit müharibələrinin iştirakçısı olur. Başqa ölkələrə müharibə elan etməkdən əvvəl KIV-də buna hazırlıq gedir. Media hibrid müharibələrinin əsas hissəsini təşkil edir. Bu, artıq əvvəlki müharibələrə bənzəmir" [4]. İndiki dövrdə bütün sahələrdəki yeniliklər, yeni çağırışlar və təhdidlərə də yol açır. İnformasiya təhlükəsiziliyinin təmin olunması üçün bunlar nəzərə alınmalı və qabaqlayıcı tədbirlər görülməlidir. $\mathrm{Bu}$ gün diqqət mərkəzində saxlanılmalı məsələlərdən biri də hibrid müharibələridir.Bəs hibrid müharibələri nədir və onlar necə xarakterizə edilir? Hibrid müharibələri birbaşa döyüş meydanlarında aparılan savaş deyil, hərbi əməliyyatların gedişinə təsir edən dolayı vasitələrdir. Bu zaman düşmən tərəf həm siyasi, iqtisadi, mənəvi-psixoloji, informativ və kommunikativ vasitələrdən istifadə edir. "Məlumatsız insan özü də bilmədən həmin müharibələrin iştirakçısına çevrilir. Özü də əksər hallarda düşmənin xeyrinə işləyir. Bunun üçün onun şüuruna əvvəlcədən müəyyən olunmuş və xüsusi məqsədlərə xidmət edən informasiyaları yeritmək kifayətdir. Sonrakı mərhələdə həmin informasiya tələsinin qurbanı kimi öz ölkəsinin, vətəninin və dövlətinin əleyhinə fəaliyyət göstərəcək. Mövcud müharibələrin ən təhlükəli cəhəti də məhz bundadır[8] .

Rəqib tərəf mümkün olan bütün vasitələrdən-cinayətkar ünsürlər, mafiya üzvləri və narkotik ticarəti, eləcə də narkotik maddələr istifadəçilərinin xidmətindən də istifadə edə bilər. Dünya təcrübəsində bu cür hallara kifayət qədər rast gəlinib. Ofqanıstan, İraq, Suriya, Meksika, Kolumbiya, Gürcüstan, Ukrayna vo Dağlıq Qarabağın timsalında hərbi əməliyyyatların təşkili, maliyyələşməsi, muzdlulardan istifadə kimi əməllər deyilənlərə sübutdur. "Dünya artıq reallıqla şahid olub ki, İKT-dən BMT-nin mexanizminə zidd surətdə kriminal və terrorçuluq məqsədilə istifadə etdikdə bu, daha dağıdıcı gücə malik silahların vurduğu ziyana bərabər tutulur. Bu cür halda informasiya silahından istifadənin "hədəfi" yalnız internetin informasiya resursları deyil, dövlətin sənaye, nəqliyyat, energetika sahələri də ola bilər." [6].

Azərbaycanın informasiya təhlükəsizliyi, milli təhlükəsuzliyi, milli maraqları konteksində ən ümdə məsələ 


\section{"Informasiya tohlükosizliyinin aktual problemlori” \\ III respublika elmi-praktiki seminarı, 08 dekabr 2017-ci il}

ərazi bütövlüyümüzün təmin olunmas1, ErmənistanAzərbaycan, Dağlıq Qarabağ münaqişəsinin həllidir. İstər 2016-c1 ilin aprelində qoşunların təmas xəttində baş verən hadisələr, istərsə də 2017-ci il iyulun 4-də Ermənistan qoşunlarının Fizuli rayonunun Alıxanlı kəndində törətdiyi hərbi təxribata münasibət bildirən Azərbaycan Respublikasının Silahlı Qüvvələrinin Ali Baş Komandanı, ölkə başçısı İlham Oliyev iyulun 12-də Nazirlər Kabinetinin 2017-ci ilin birinci yarısının yekunlarına və qarşıda duran vəzifələrə həsr olunan iclasında bəyan etdi ki, "bizim xarici siyasətimizin əsas məsələsi Ermənistan-Azərbaycan, Dağlıq Qarabağ münaqişəsidr. Ofsuslar olsun ki, bu ilin birinci yarısında bu istiqamətdə heç bir nəticə əldə edilməmişdir. Bununla bərabər, hesab edirəm ki, 2017-ci ildə münaqişənin həlli ilə bağlı önəmli hadisələr də baş vermişdir və Azərbaycanın haqlı mövqeyi daha da böyük dəyər qazanmışdır." Çıxışında Ermənistanın danışıqlardakı destruktiv mövqeyino toxunan prezident İlham Oliyev bildirdi ki, "aprel hadisələrindən sonra Ermənistan danışıqların bərpa edilməsi üçün bir neçə şərt qoyurdu və bunu açıq şəkildə bəyan edirdi. Mən o vaxt yenə də görürdüm, bilirdim ki, bu, növbəti axmaqlıqdır. Çünki, gec-tez onlar danışıqlar masasına qayıdacaqlar, sadəcə olaraq, özlərini olmayan hörmətdən növbəti dəfə salacaqlar. Belə də oldu’[2].

Alıxanlı hadisəsinə də diqqət yönəldən Prezident İlham Oliyev balaca Zəhranın və onun nənəsinin öldürülməsinin erməni faşizminin eybəcər sifətini bütün dünyaya göstərdiyini dedi. Baş verən hadisələrin dünya ictimaiyyətinə çatdırılması məsələsinə də münasibət bildirən ölkə başçısı söylədi ki, "Bizim bütün qurumlarımız çox fəal, operativ işlədilər, bu məlumatı dünya ictimaiyyətinə çatdırdılar. Həm dövlət qurumları, səfirliklər, diaspor təşkilatları, ictimai təşkilatlar, bizim xaricdəki dostlarımız öz səslərini ucaltdılar və Ermənistana, onun faşist xislətli siyasi rəhbərliyinə dünyada nifrot daha da artdı"[2].

İKT-nin geniş inkişafı öz faydaları ilə yanaşı, problemlərə də səbəb olur. Hazırda geniş yayılmış kibercinayətkarlıq istənilən sahədə, istənilən vaxtda işi iflic edə, ciddi zərbə vura bilər. Buna görə də virtual aləmdə real və potensial rəqibin bu cür hücumlarının qarşısını almaq üçün hər bir ölkədə, hər bir fəaliyyət sahəsində texnoloji tədbirlər görülməli, güclü antivirus proqramları hazırlanmalı, təhlükəsizlik təmin olunmalıdır. Belə ki, "İKT-nin zəif inkişafı dövlətin müasir inteqrasiya proseslərində, beynəlxalq münasibətlərin və iqtisadiyyatın inkişafinda geri qalmasına səbəb olur. İnternet dünya siyasi və iqtisadi arenasında nifuz və təsiri özündə birləşdirir, strateji məqsədlərə nail olmağa, milli təhlükəsizliyin, geosiyasi məsələlərin həllinə imkan verir" [5]

Təcrübə göstərir ki, informasiya təhlükəsizliyinə təhdidlərin qarşısı vaxtında və təsirli tədbirlərlə alınmasa, müdafiə və digər milli maraqlara ciddi zərbə vurula bilər. Təhlükəsizliklə bağlı məsələ Azərbaycan Respublikasının Prezidenti İlham Oliyevin 2017-ci il sentyabrın 27-də Belarus Respublikasının Təhlükəsizlik Şurasının dövlət katibi Stanislav Zasla görüşündə də diqqət mərkəzində olub. "Dövlətimizin başçısı Azərbaycan ilə Belarus arasında dostluq və qardaşlıq münasibətlərinin müxtəlif istiqamətlərdə təhlükəsizlik, iqtisadiyyat, energetika, ticarət, hərbi-texniki əməkdaşlıq və digər sahələrdə uğurla inkişaf etdiyini vurğulayıb. Təhlükəsizlik sahəsinə toxunan Prezident İlham Oliyev qeyd edib ki, bununla bağlı müzakirə olunası və birgə fəaliyyət göstəriləsi bir çox məsələlər var. Dövlətimizin başçısı bildirib ki, dünyada təhdidlər artır və təhlükəsizlik məsələləri dövlətlər üçün prioritet sahəyə çevrilir" [1]. Göründüyü kimi, ölkə rəhbəri, möhtərəm prezidentimiz İlham Oliyev həm rəsmi şəxslər, həm də müvafiq beynəlxalq təşkilatların nümayəndələri ilə görüşlərdə ikitərəfli münasibətlərlə yanaş1, təhlükəsizlik məsələlərini daim diqqət mərkəzində saxlayır, müzakirə edir. Həm daxili, həm də xarici siyasətlə bağlı fikir mübadiləsi hər bir tərəfin maraqlarına xidmət edir və bu sahədə lazımı addımlar atılır.

\section{NəTİCə}

$\mathrm{Bu}$ gün KIV və onun aparıcı qüvvəsi olan jurnalistlərin üzərinə xüsusilə böyük məsuliyyət düşür. Çünki, onlar bəzən silahdan da güclü olan söz sahibi, yaradıcı şəxslər və təbliğatçıdırlar. Bununla belə, jurnalistlər onlara verilən bu imkandan sui-istifadə etməməli, qanunlar çərçivəsində fəaliyyət göstərməli, dövlətin konstitusion quruluşuna qarş1 çıxmamal1, vətəni sevməli, insanlarda vətənpərvərlik hissləri aşılamalı, eyni zamanda zorakılıq və qəddarlığı təbliğ etməməli, öz peşələrinə vicdanla yanaşmalıdırlar. Beləki, informasiya təhlükəsiziliyi cəmiyyətin mövcudluğu, onun inkişafı, dövlətçiliyin saxlanılması üçün mühüm əhəmiyyət daşıyır. İnformasiya texnologiyalarından səmərəli istifadə isə bu işə əlavə stimul verir və təhlükəsizliyin təminatı üçün əsas yaradir.

\section{ӘDӘBIYYYT}

[1] Prezident İlham Điyev BelarusunTəhlukəsizlik Surasinin dovlət katibini qəbul edib- ttps://azertag.az/xeber/1097330

[2] Prezident İlham Đliyevin sədrliyi ilə Nazirlər Kabinetinin 2017-ci ilin birinci yarısının sosial-iqtisadi inkişafının yekunlarına və qarşıı duran vəzifələrə həsr olunan iclasında İlham Oliyevin giriş nitqi. http://www.president.az/articles/24725

[3] Babaoğlu H. Heydər Oliyev siyasi irsinin politoloji aspektləri, "MSA", Bak1, 2013

[4] http://palitranews.az/news.php?id=71941

[5] Oləkbərova L. Müasir beynəlxalq münasibətlər sistemində baş verən proseslərdə İKT-nin yeri və rolu, «Strateji təhlil “ jurnalı, sayı 3-4 (1718), 2016,səh-153

[6] Y. Yorozu, M. Hirano, K. Oka, and Y. Tagawa, "Electron spectroscopy studies on magneto-optical media and plastic substrate interface," IEEE Transl. J. Magn. Japan, vol. 2, pp. 740-741, August 1987.

[7] Крутских А, Стрельцов А. Международное право и проблема обеспечения международной информационной безопасности. Журнал - Международная Жизнь, Проблемы внешней политики, дипломатии, национальной безопасности, 2014, с-20-21

[8] Никонов С. В. Устойчивый феномен глобализации. http://www.nauteh-journal.ru/index.php/en/--gn12-02/402

[9] Поценцов Г. Гибридно-информационная война: основные характеристики, http://www.osvita.mediasapiens.ua/trends/1411978127/ 


\section{INFORMATION SECURITY IN AZERBAIJAN IN THE} CONTEXT OF NATIONAL INTERESTS

Elshad Hasanli

Institute of Information Technologies of ANAS xeber36@aztv.az.

Abstract - Maintenance of security of each and every state and society and the provision of political and other interests of people are among the major tasks in modern times in the international arena at the time where tendencies for political confrontations are observed. In the times where science, technology and information technologies are developed and widely applied, information security is specifically becoming a priority issue. The character of national interests, their prioritization in all the directions of state policy, including in the field of information security is a subject of this research. The research analyses the works carried out in order to provide for information security in the Republic of Azerbaijan and touches on the necessary measures undertaken to prevent foreign threats in this field.

Keywords - state, national security, information security, national interests, hybrid wars, information protection, terrorism, multiculturalism, media 